\title{
Elaboration and validation of a protocol for safe administration of enteral nutrition in hospitalized patients
}

\author{
Elaboração e validação de um protocolo para administração \\ segura de nutrição enteral em pacientes hospitalizados \\ Elaboración y validación de un protocol de administración segura \\ para la nutrición enteral en pacientes hospitalizados
}

\author{
Andréia Barcellos Teixeira Macedo ${ }^{a}$ \\ Michelli Cristina Silva de Assis ${ }^{a}$ \\ Kelly Cristina Milionia \\ Débora Francisco do Canto ${ }^{a}$ \\ Célia Mariana Barbosa de Souza ${ }^{a}$ \\ Enaura Helena Brandão Chaves ${ }^{b}$
}

How to cite this article: Macedo ABT, Assis MCS, Milioni KC, Canto DF, Souza CMB, Chaves EHB. Elaboration and validation of a protocol for safe administration of enteral nutrition in hospitalized patients. Rev Gaúcha Enferm. 2021;42(spe):e20200181. doi: https://doi.org/10.1590/19831447.2021.20200181 aspital de Clínicas de Porto Alegre (HCPA). Porto Alegre, Rio Grande do Sul, Brasil.

Universidade Federal do Rio Grande do Sul (UFRGS). Porto Alegre, Rio Grande do Sul, Brasil.

\section{ABSTRACT}

Objective: To describe the elaboration and validation of a protocol for administration of enteral nutrition.

Method: Validation study by consensus of experts conducted in a university hospital. The construction took place after literature review. The validation was guided by the tool: plan, do, study and act. For validation of the final protocol, 100\% consensus was considered. After implementation, preceded by training, evaluation was carried out by using indicators.

Results: The protocol describes the actions that guide the nursing team in enteral nutrition. In the validation, there was a 100\% consensus on the protocol items. The presential training brought together 425 participants in 80 meetings. After the pilot period, the rate of care for patients with enteral nutrition increased from $39.5 \%$ to $73.3 \%$. There was a reduction of 41 hours in the time to release the X-ray report.

Conclusion: The protocol provided elements for the prevention of adverse events in patients with enteral nutrition.

Keywords: Protocols. Enteral nutrition. Nursing care.

\section{RESUMO}

Objetivo: Descrever a elaboração e validação de um protocolo para administração de nutrição enteral.

Método: Estudo de validação por consenso de especialistas conduzido em um hospital universitário. A construcãa ocorreu após revisão da literatura. A validação foi norteada pela ferramenta plan, do, study and act. Para validação do protocolo final foi considerado consenso de 100\%. Após a implantação, precedida de capacitação, ocorreu a avaliação por meio de indicadores.

Resultados: 0 protocolo descreve as ações que guiam a equipe de enfermagem na nutrição enteral. Na validação, ocorreu consenso de 100\% nos itens do protocolo. A capacitação presencial reuniu 425 participantes em 80 encontros. Após o período piloto, a taxa de cuidado ao paciente com nutrição enteral aumentou de 39,5\% para 73,3\%. Houve redução de 41 horas no tempo para liberação do laudo do raio $X$

Conclusão: 0 protocolo forneceu elementos para a prevenção de eventos adversos em pacientes com nutrição enteral.

Palavras-chave: Protocolos. Nutrição enteral. Cuidados de enfermagem.

\section{RESUMEN}

Objetivo: Describir la elaboración y validación de un protocolo para la administración de nutrición enteral.

Método: Estudio de validación por consenso de expertos realizado en un hospital universitário. La construcción se llevó a cabo después de revisar la literatura. La validación estuvo guiada por la herramienta plan, do, study and act. Para la validación del protocolo final se considero un consenso del 100\%. Después de la implementación, precedida por la capacitación, se llevó a cabo la evaluación mediante indicadores.

Resultados: El protocolo describe las acciones que orientan al equipo de enfermería en nutrición enteral. En la validación , hubo un consenso del 100\% en los ítems del protocolo. La información presencial reunió a 425 participantes en 80 reuniones. Después del período piloto, la tasa de atención a los pacientes con nutrición enteral aumento del 39,5\% al 73,3\%. Hubo una redución de 41 horas en el tiempo para publicar el informe de rayos $X$.

Conclusión: El protocolo aportó elementos para la prevención de eventos adversos en pacientes con nutrición enteral. Palabras clave: Protocolos. Nutrición enteral. Atención de enfermería. 


\section{口INTRODUCTION}

In the year of 2020, nursing was graced worldwide through the Nursing Now campaign. Professionals in the field are being valued for working alongside hospitalized patients, supplying all their basic human needs. Food, in turn, is one of the fundamental needs for the overall recovery of the individual ${ }^{(1)}$, with nursing being responsible for ensuring that care for food intake or supply of nutrients is done effectively ${ }^{(2)}$.

Enteral nutrition (EN) is an important technological advance, which contributes to the improvement of the general condition of patients ${ }^{(1)}$. The nasoenteral tube (NET) diet is essential for those patients who are unable to ingest the minimum amount of nutrients orally to supply basic organism functions ${ }^{(2)}$.

Despite the documented benefits, enteral nutritional therapy (ENT) adds risks to patient safety. The main complications include accidental displacement of the NET, positioning in the respiratory tract and microaspiration. When following 150 NET insertions, a study ${ }^{(3)}$ identified 169 situations where the patient was exposed to risk, among them, the presence of verbal guidance for insertion of NET (35\%), absence of positioning control radiography (6.5\%) and failure to release the NET for use (7.1\%). There were 30 incidents, with 23 NET accidental escape $(n=23)$ and 7 NET administrations after breaking security barriers. There was one serious adverse event of bronchoaspiration ${ }^{(3)}$.

Pneumonia in patients with NET is little described in studies addressing the problem and, therefore, it becomes difficult to establish this causality. It is known that the use of preventive measures reduces this infection ${ }^{(4)}$. Pneumonia in a patient without mechanical ventilation is twice as frequent as that associated with mechanical ventilation and is related to increased morbidity and mortality ${ }^{(4)}$.

The delay between the NET indication and the beginning of the first diet is a warning to health professionals about the risk of hospital malnutrition. Research carried out in an emergency department has shown that the time between insertion of the tube and the installation of the EN can exceed 10 hours, varying between 63 and 3120 minutes. The reasons identified for this delay were factors related to the care organization, the prescription of the diet and the patient's conditions ${ }^{(5)}$.

In view of this scenario, a teaching hospital in the south of Brazil noted the need to review the current EN process. A routine follow-up at the institution found that $99 \%$ of hospitalized patients have some nutritional risk, with 15.4\% of them using EN. In 2015, 219 (27.6\%) patients were diagnosed with pneumonia unrelated to mechanical ventilation, of which $33 \%$ were using NET.

Patient safety corresponds to the reduction to the minimum acceptable risk of unnecessary damage associated with health care, it has gained increasing prominence in health institutions worldwide ${ }^{(6)}$. In Brazil, the Brazilian Network for Nursing and Patient Safety (REBRAENSP) was established, whose role is to implement a patient safety culture ${ }^{(7)}$. To improve patient safety, a safety culture policy is essential, although this is one of the most difficult steps for an institution. Guides, application of checklist, strategies with active learning methodology, such as simulation, have been evaluated in clinical nursing practice in order to consolidate the patient safety culture ${ }^{(8-9)}$.

The use of protocols can be a strategy for patient safety under EN in order to standardize the conduct among professionals. The protocol is a simple and effective tool that helps to prevent and reduce the risks caused during health care and nursing has been working with care protocols in recent years ${ }^{(10)}$.

In a year of visibility to the nursing role, the intention is to disseminate the elaboration of a protocol in $\mathrm{EN}$, in which the nurse is the protagonist of the process. In addition to reducing the risks for the patient, this protocol provides autonomy and enables the nurse's empowerment during the care of patients with $\mathrm{EN}^{(2)}$. Among the axes of the Nursing Now campaign, it is an effective and innovative nursing practice based on scientific evidence at the regional level, but which can be multiplied for other institutions in $\operatorname{Brazi}(7,10)$.

The justification for this investigation is based on the importance of producing and adding knowledge about the topic to support activities of prevention and health promotion in patients with EN use. Also, studies on the role of nurses in EN are still scarce.

Thus, the guiding question that conducted this present study was: "What care should comprise a care protocol for the safe administration of enteral nutrition in hospitalized patients using NET?"The study aimed to describe the design and validation of a protocol for the safe administration of enteral nutrition in hospitalized patients.

\section{METHOD}

Methodological study, which describes the development and validation of a protocol for the safe administration of EN in hospitalized patients. Validation studies by consensus among specialists allow collective opinion or agreement 
among specialists to be reached regarding a specific phenomenon and have been used in nursing to define standards of practice ${ }^{(11)}$.

The construction and validation of the protocol were guided by the theoretical framework of the Institute for Healthcare Improvement, which advocate the PDSA tool (Plan, Do, Study and Act) ${ }^{(12)}$, which allows the process to be reassessed at each stage: construction, validation, implementation and evaluation. To evaluate the levels of evidence of the proposed items in the protocol, it was used the GRADE classification ${ }^{(13)}$.

The research was carried out from January to September 2018, in a tertiary, highly complex and university hospital in southern Brazil. The institution has 842 beds and a structure for diagnosis and treatment of various pathologies in 60 specialties, with 6116 employees. Twelve inpatient units were included, 5 clinics (190 beds) and 7 surgical units (395 beds). In these areas, an average of 82 patients/day use NET.

The protocol was elaborated and validated by the working group Safety and Efficacy in Assisting Patients in Enteral Nutritional Therapy, formed by three assistential nurses, a nurse from the Nutrition Support Committee, a nutritionist physician, a physician from the Hospital Infection Control Committee, two nurse professors and a nutritionist. The team held weekly meetings, and the deliberations were recorded in minutes.

The construction of the protocol took place according to the following steps: situational diagnosis carried out by the Nutritional Support and Hospital Infection Control committees, through the evaluation of institutional documents and observation of nursing care in the inpatient units, which identified the use of methods not accurate or safe to verify the tube positioning as the auscultation test. In this stage, it was verified the lack of standardization in the care provided and records of the infused volume of EN; literature review (with the keywords enteral nutrition, protocols, nursing in the Pubmed and Scielo databases), which supported the need to change the processes in force at the institution; two regional nursing councils, and their respective publications, a technical opinion ${ }^{(14)}$ and a reasoned guidance ${ }^{(15)}$, subsidized the institutional protocol in the stage of carrying out the NET control radiography; meeting with the heads of the areas to present the protocol; review of the care prescription by the Nursing Process Commission of the institution under study, based on the nursing diagnoses registered in the hospital management application according to the standardized nursing language of NANDA International (NANDA-I) ${ }^{(16)}$.

The validation and final consensus took place during periodic meetings held by the working group in order to discuss each stage of the EN administration process, seeking to clarify doubts, in the light of examples from the assistance routine and evidences from the literature. With support in these discussions, the protocol items were validated. It was considered consensus at the expert group meetings the $100 \%$ agreement on the entire protocol.

The implantation (pilot test) of the protocol was carried out in two units of clinical hospitalization. After two months, it was expanded to other areas. For the implementation of the protocol, the assistance team was sensitized and received presential training in a teaching laboratory on the performance of the proposed activities and the importance of adhering to their stages; nurses received specific training on the protocol activities; training and sensitization of the other teams involved with EN (physicians, nutritionists and speech therapists). The sensitization and training of the assistance team took place in person and included the participation of nursing technicians and nurses.

The use of the protocol predicts for the evaluation stage by monitoring quality and effectiveness indicators defined by the researchers. The stipulated indicators to evaluate the implementation of the protocol were: adherence to the protocol items and time to release the X-ray of NET control. The indicators analysis was performed using simple descriptive statistics. To assess the percentage of adherence to the protocol items, the Chi-square test and the Mann-Whitney test were used for the NET release time. The researchers followed the implementation, providing relevant guidance. It also predicts rounds of conversation with the nursing team, aiming to collect the perception about the protocol, benefits, and points for improvement.

The project was approved by the Research Ethics Committee under number 19-0198 and CAAE statement: $01765418,0,0000,5327$. The authors signed a Term of Commitment for the Use of Data, to have access to the minutes of the work meetings, committing to preserve the privacy and anonymity of those involved.

\section{$\square$ RESULTS}

The result of this research was the construction and validation of a protocol for the safe administration of EN in hospitalized patients. Below are described the results of each stage of elaboration and final formatting, which is presented in Chart 1.

From the literature review, the evidence brought to the fore that the X-ray is the gold standard method in confirming the positioning of the $\mathrm{NET}^{(1,17-18)}$. Studies ${ }^{(4,18)}$ point out that the standardization of bedside care for patients with NET has an impact on the prevention of associated respiratory infections. Essential care at the bedside is oral hygiene three times a day, 


\section{Nasoenteral tube insertion}

- Perform hand hygiene; (IA)

- Check the patient's identification; (IC)

- Guide procedure;

- Insert the nasoenteral tube according to the institution's standard operating procedure; (IA)

- Check the initial external measurement of the nasoenteral tube after insertion; (IlaC)

- Request abdomen radiography to check the nasoenteral tube position; (IA)

- Release the use of the nasoenteral tube for diet or medication according to the institutional protocol: the radiologist will describe the positioning of the device in the examination report. The nurse can release the nasoenteral tube when the extremity is in gastric or duodenal projection. (IA)

- Provide support during the procedure; (IC)

- Assist in positioning for NET installation; (IC)

- Wait for the NET release to start the EN. (IC)

Enteral nutrition administration and monitoring

- Start a nursing diagnosis pertinent to the nutrition subgroup. (IC)

- Perform a nursing prescription containing: elevated headboard $30-45^{\circ}$, oral hygiene $3 x$ daily with antiseptic, daily nasal hygiene, checking the external measurement of the tube, keeping it according to the initial measurement, changing the fixation of the nasoenteral tube whenever necessary. (IC)

- Reassess the position of the nasoenteral tube, by means of a new radiological examination, in case of accidental traction of the nasoenteral tube greater than or equal to $5 \mathrm{~cm}$. (IC)
- Check the external measurement of the nasoenteral tube before administration of each diet or medication. If diet in closed system, once, every six hours. (llaC)

- Record in the patient's record, in the column nasoenteral tube $(\mathrm{cm})$ - the external measurement of the nasoenteral tube. (IC)

- Manage the diet through a nasoenteral tube according to the institution's standard operating procedure. (IlaC)

- Perform the care according to the nursing prescription, before, during and after the administration of the diet by nasoenteral tube. (IlaC)

- Record in the patient's record the nursing care performed, and the volume of diet administered. (IlaC)

- Inform the nurse if there is a change higher than or equal to $5 \mathrm{~cm}$ from the initial external measurement of the nasoenteral tube. (IlaC)

End of enteral nutrition or hospital discharge

- Provide guidance, in case of hospital discharge with a nasoenteral tube, for the administration of the diet at home, organize the supplies and instrumentalize the family or caregiver for the use of the device. (IC)
- Assist family or caregiver for care in administering diet or medication by nasoenteral tube. (IlaC)

Chart 1 - Protocol for safe administration of enteral nutrition in adult hospitalized patients. Porto Alegre, RS, 2020 Source: Authors, 2020. 
nasal hygiene every 24 hours, elevated headboard, minimum at $30^{\circ}$, during diet infusion, changing the NET fixation every 24 hours and whenever there is dirt or oiliness ${ }^{(18)}$

The validation step, in addition to $100 \%$ consensus and agreement on all protocol items, resulted in: a) Participation of research members in meetings with heads of medical and nursing services to expose the problem and the protocol proposal; b) Two-hour presential meetings, previously scheduled for the professionals involved, aiming at raising sensitization and training on the change in the work process; c) Weekly meetings of the working group to check the actions progress, listening to the nursing leaders who were with the care teams (feedback meetings) and planning the next stages of the process.

During the pilot test period, it was verified the need for visits to the assistance areas in order to monitor in loco the protocol implementation. On that occasion, it was identified the importance of making the protocol available in writing at the units. Thus, physical copies were affixed to the units' dissemination murals. However, after the pilot, it did not culminate in changing the protocol items.

The sensitization and training of the assistance team resulted in a total of 80 meetings and 425 participants. Such training led to improvements in patient care, this received the enteral diet more quickly and effectively, according to the monitoring of the indicators.

The indicators were monitored by the working group, after the two-month test period in each inpatient unit. The general adherence rate to care for patients with NET increased before the protocol was $39.5 \%$ after $73.3 \%$. In addition, there was a reduction of 41 hours in the time to release the X-ray report of NET control and start of EN administration.

This protocol allowed nurses to request the radiographic examination, and based on the report issued by the radiologist, the NET could be released for use. In the absence of the report, the NET control X-ray must be evaluated by the physician, who may make use or not the enteral feeding device.

The listed activities in the protocol, which present scientific evidence, performed by nurses and nursing technicians, were classified according to the degree of recommendation and evidence level.

\section{DISCUSSION}

This study presented the stages of elaboration and validation of a protocol for safe administration of enteral nutrition based on a consensus of specialists in the area. The creation of this protocol corresponds to an innovative strategy in the year of the Nursing Now Campaign, as it guided the actions performed by nursing. The present protocol, contemplated in the theme that highlights the role of nursing, was able to guarantee adequate nursing care and offer EN with safety and quality in the hospital institution under study.

The legislation (2) that supports good practices in EN, mentions that the nurse and his team are responsible for inserting the NET, administering the EN and monitoring the patient. Within this context, it is inferred that this study is the first that associated the monitoring of quality indicators and the effectiveness of a protocol, based on the PDSA management tool.

Few intervention studies have used the PDSA in nursing. Thus, it is perceived that this tool has great value as a guide for assistance actions and collaborates in obtaining better results. This research also deserves to be highlighted when using the consensus validation methodology, which is still incipient in nursing studies ${ }^{(19)}$.

It was identified only a single study in the literature that aimed to build and validate an EN protocol for adult patients using NET. Fifteen specialists were included, with a concordance index of 0.83 , considered high reliability. The authors conclude that the protocol can be applied in practice, but they have not tested $i^{(20)}$. Our study, on the other hand, built and validated the EN protocol in healthcare practice.

The team's adherence to the protocol was considered a fundamental factor for obtaining good quality results. A research conducted in the country of Ghana, which also assessed the team's adherence, found that adherence was higher among nursing assistants than among nurses $(O R=2.76$, $p=0.031$ ). The barriers pointed out were little opportunity for in-service training and insufficient protocols about care with $\mathrm{NET}^{(21)}$. It is understood that the participation in the training of all professionals in the sectors where the protocol would be implemented contributed to the effectiveness of the starting of the same.

A study ${ }^{(22)}$ that evaluated the use of the Standard Operating Procedure (SOP) by nursing, identified weaknesses such as the reduced number of professionals, inadequate physical structure and absence of materials. The protocol presented in this study differs from SOP(23), as it is not restricted to its dissemination only. The implementation of this protocol went further, as it provided stages, ranging from the verification of available supplies to the need for qualified human resources.

The use of SOP in nursing care practice is widely applied in the health institution where this study was conducted. However, there are still gaps in patient care under EN, a fact that justifies the implementation of this protocol. 
It is noteworthy that essential care at the bedside is essential in preventing pneumonia associated with $\mathrm{NET}^{(4)}$. Therefore, the protocol of this study can be combined with the reduction of this hospital infection since it objectively standardized care for patients in EN.

Thus, the creation of nursing protocols is essential for the performance of the activities in which nursing is involved. The use of a protocol in care allows integrating care theory and practice, discouraging ritualistic actions. It is believed that nurses have an important role in promoting the health of people using EN, as a health educator, responsible for patient care and looking for improvements, seeking strategies to promote the quality of care provided ${ }^{(23)}$. Thus, the nurse, as well as the other health professionals, when using the EN protocol, performs differentiated care, striving for care that brings together research and care practice.

\section{CONCLUSIONS}

This study achieved its objective by elaborating and validating an enteral nutrition protocol through consensus among specialists, which has been used in the institution in all areas of adult hospitalization, thus portraying its local applicability. After the protocol consolidation in these areas, there was an expansion to pediatric, emergency, intensive care, and outpatient surgical centers.

The implementation of the protocol allows the organization of care, actions that involve the patient care in need of nutritional support, the definition of the duties of each professional involved and the improvement in the safety and quality of the in-hospital nutrition process. It also allows autonomy, involvement, and accountability of the nursing team in care, characteristics foreseen in the Nursing Now campaign.

As a limitation of the study, external validity can be cited since its implementation may be different in other health contexts. However, it is suggested to carry out similar studies, in other scenarios, in order to compare the present findings. Each health institution has specificities that can be shaped so that the proposed protocol is feasible for each reality that presents itself. Even so, it is concluded that the material exposed here derives from a pioneering study in the nursing field and can contribute to the qualification of care and safety for patients with enteral nutrition.

\section{REFERENCES}

1. Mueller CM, Lord LM, Marian M, McClaveS, Smith SJ. The ASPEN Adult Nutrition Support Core Curriculum. $3^{\text {rd }}$ edition. Silver Spring, MD: American Society for Parenteral and Enteral Nutrition; 2017.
2. Agência Nacional de Vigilância Sanitária (BR). Resolução Diretoria Colegiada. RDC no 63 de 6 de julho de 2000. Aprova o regulamento técnico para fixar os requisitos mínimos exigidos para a terapia de nutrição enteral. Brasília, DF; 2000 [cited 2020 Apr 10]. Available from: https:// www20.anvisa.gov.br/segurancadopaciente/index.php/legislacao/item/ resolucao-da-diretoria-colegiada-rcd-n-63-de-6-de-julho-de-2000

3. Anziliero F, Beghetto MG. Incidents and adverse events in enteral feeding tube users: warnings based on a cohort study. Nutr Hosp 2018;35(2):259-64. doi: https://doi.org/10.20960/nh.1440

4. Lacerna CC, Patey D, Block L, Naik S, Kevorkova Y, Galin J. A successful program preventing nonventilator hospital-acquired pneumonia in a large hospital system. Infect Control Hosp Epidemiol 2020;41(5):547-52. doi: https://doi. org/10.1017/ice.2019.368

5. Anziliero F, Corrêa APA, Silva BA, Soler BED, Batassini E, Beghetto MG. Nasoenteral tube: factors associated with delay between indication and use in emergency services. Rev Bras Enferm. 2017;70(2):326-34. doi: https://doi. org/10.1590/0034-7167-2016-0222

6. Matiello RDC, Lima EFA, Coelho MCR, Oliveira ERA, Leite FMC, Primo CC. Patient safety culture from the perspective of nurses. Cogitare Enferm. 2016;21(5). doi: https://doi.org/10.5380/ce.v21i5.45408

7. Caldana G, Guirardello EB, Urbanetto JS, Peterlini MAS, Gabriel CS. Brazilian Network for Nursing and Patient Safety: challenges and perspectives. Texto Contexto Enferm. 2015;24(3):906-11. doi: https://doi. org/10.1590/0104-070720150001980014

8. Cardoso ASF, Muller S, Echer IC, Rabelo-Silva ER, Boni FG, Ribeiro AS. Elaboration and validation of a drug administration checklist for patients in research protocols. Rev Gaúcha Enferm. 2019;40(spe):e20180311. doi: https://doi. org/10.1590/1983-1447.2019.20180311

9. Corrêa APA, Nora CRD, Sousa GP, Santos VJ, Viegas GL, Agea JLD, et al . Risks of enteral nutritional therapy: a clinical simulation. Rev. Gaúcha Enferm. 2020;41(spe):e20190159. doi: https://doi. org/10.1590/1983-1447.2020.20190159

10. Sartor GD, Silva BF, Masiero AV. Patient safety in large-sized hospitals: panorama and challenges. Cogitare Enferm. 2016;21(5). doi: https://doi.org/10.5380/ ce.v21i5.45644

11. Pinheiro JQ, Farias TM, Abe-Lima JY. Painel de especialistas e estratégia multimétodos: reflexões, exemplos, perspectivas. Psico. 2013 [cited $2020 \mathrm{Apr}$ 10];44(2):184-92. Available from: https://revistaseletronicas.pucrs.br/ojs/ index.php/revistapsico/article/view/11216

12. Institute for Healthcare Improvement (US). PDSA worksheet. Boston, MA: Institute for Healthcare Improvement; 2016 [cited 2020 Apr 10]. Available from: http:// www.ihi.org/education/IHIOpenSchool/resources/Assets/PDSAworksheet_ Instructions.pdf

13. Ministério da Saúde. Secretaria de Ciência, Tecnologia e Insumos Estratégicos. Departamento de Ciência e Tecnologia. Diretrizes metodológicas: Sistema GRADE - manual de graduação da qualidade da evidência e força de recomendação para tomada de decisão em saúde. Brasília: Ministério da Saúde; 2014 [cited 2020 Apr 10]. Available from: http://bvsms.saude.gov.br/bvs/ publicacoes/diretrizes_metodologicas_sistema_grade.pdf

14. Conselho Regional de Enfermagem do Distrito Federal (BR). Parecer Técnico Coren-DF 17/2011 de 18 de outubro de 2011. 0 enfermeiro pode solicitar 0 exame de RX de abdome, para certificar o posicionamento da sonda nasogástrica ou nasoenteral? Brasília, DF; Coren-DF; 2011 [cited 2020 Apr 10]. Available from: https://www.coren-df.gov.br/site/parecer-tecnico-coren-df-172011/ 
15. Conselho Regional de Enfermagem de São Paulo (BR). Câmara Técnica. Orientação Fundamentada № 007/2017. Avaliação de exame de RX para inserção de sonda nasoenteral. São Paulo: Coren-SP; 2017 [cited 2020 Apr 10]. Available from: https://portal.coren-sp.gov.br/wp-content/uploads/2017/02/ Orienta\%C3\%A7\%C3\%A30\%20Fundamentada\%20-\%20007_2.pdf

16. Herdman TH, Kamitsuru S. NANDA International Nursing Diagnoses: definitions and classification 2018-2020. 11 $\mathrm{ed}$. New York: Thieme; 2018.

17. Bourgault AM, Halm MA. Feeding tube placement in adults: safe verification method for blindly inserted tubes. Am J Crit Care 2009;18(1):73-6. doi: https:// doi.org/10.4037/ajcc2009911

18. Gimenes FRE, Pereira MCA, Prado PRD, Carvalho REFL, Koepp J, Freitas LM, et al. Nasogastric/Nasoenteric tube-related incidents in hospitalised patients: a study protocol of a multicentre prospective cohort study. BMJ Open. 2019;9(7):e027967. doi: https://doi.org/10.1136/bmjopen-2018-027967

19. Leite SS, Áfio ACE, Carvalho LV, Silva JM, Almeida PC, Pagliuca LMF. Construction and validation of an Educational Content Validation Instrument in Health. Rev Bras Enferm. 2018;71(Suppl 4):1635-41. doi: https://doi. org/10.1590/0034-7167-2017-0648

\section{- Authorship contribution:}

Conceptualization: Andréia Barcellos Teixeira Macedo, Michelli Cristina Silva de Assis.

Data curation: Michelli Cristina Silva de Assis.

Formal analysis: Andréia Barcellos Teixeira Macedo, Michelli Cristina Silva de Assis.

Methodology: Andréia Barcellos Teixeira Macedo, Michelli Cristina Silva de Assis.

Project administration: Andréia Barcellos Teixeira Macedo, Michelli Cristina Silva de Assis, Kelly Cristina Milioni, Débora Francisco do Canto, Célia Mariana Barbosa de Souza, Enaura Helena Brandão Chaves. Writing-original draft: Andréia Barcellos Teixeira Macedo, Michelli Cristina Silva de Assis, Kelly Cristina Milioni, Débora Francisco do Canto, Célia Mariana Barbosa de Souza, Enaura Helena Brandão Chaves.

Writing-review \& editing: Andréia Barcellos Teixeira Macedo, Michelli Cristina Silva de Assis, Kelly Cristina Milioni, Débora Francisco do Canto, Célia Mariana Barbosa de Souza, Enaura Helena Brandão Chaves.

\section{- Corresponding author:}

Andréia Barcellos Teixeira Macedo

Email:amacedo@hcpa.edu.br
20. Campos FA, Caetano JA, Almeida PC, Silva VM. Enteral nutrition therapy: protocol construction and validation. Rev Enferm UERJ. 2016;24(2):e11625. doi: https://doi.org/10.12957/reuerj.2016.11625

21. Alhassan RK, Tsikata R, Tizaawaw RN, Tannor PA, Quaw PP, Awortwi CAA, et al. Adherence to standard nursing protocols on nasogastric tube feeding in a secondary referral hospital in Ghana: comparing self-ratings by professional and auxiliary nurses. BMC Health Serv Res. 2019;19:119. doi: https://doi. org/10.1186/s12913-019-3931-6

22. Sales CB, Bernardes A, Gabriel CS, Brito MFP, Moura AA, Zanetti ACB. Standard Operational Protocols in professional nursing practice: use, weaknesses and potentialities. Rev Bras Enferm. 2018;71(1):126-34. doi: https://doi. org/10.1590/0034-7167-2016-0621

23. Figueiredo TWB, Mercês NNA, Lacerda MR, Hermann AP. Developing a nursing healthcare protocol: a case report. Rev Bras Enferm. 2018;71(Suppl 6):2837-42. doi: https://doi.org/10.1590/0034-7167-2017-0846

\section{Associate editor:}

Dagmar Elaine Kaiser

Editor-in-chief:

Received: 06.24.2020

Approved: 10.05.2020
Maria da Graça Oliveira Crossetti 